\title{
混合砂礫河床変動モデルの構築と 粗粒化・細粒化を伴う河床変動への適用 NUMERICAL MODEL FOR GRAVEL TRANSPORT AND ITS APPLICABILITY TO BED DEGRADATION AND AGGRADATION WITH ARMOURING AND DOWNSTREAM FINING
}

\author{
重枝未玲 $^{1} \cdot$ 秋山壽一郎 ${ }^{2} \cdot$ 坂本 洋 $^{3}$ \\ Mirei SHIGE-EDA, Juichiro AKIYAMA and Hiroshi SAKAMOTO \\ 1正会員 博士（工）九州工業大学大学院准教授 工学研究院建設社会工学研究系 \\ （广804-8550 北九州市戸畑区仙水町1-1） \\ 2 フェロー会員 Ph.D. 九州工業大学大学院教授 工学研究院建設社会工学研究系 (同上) \\ 3正会員（株）建設技術研究所 九州支社河川部 (下810-0041 福岡市中央区大名2-4-12 CTI福岡ビル) \\ 九州工業大学大学院 工学研究科建設社会工学専攻博士後期課程
}

\begin{abstract}
Numerical model for gravel transport was developed. The model employs relation for hiding and bedload transport of mixtures of Ashida and Michiue (1972) and Wilcock and Croew (2003) and links grain size distributions in the bed load, surface layer and subsurface with the gravel transfer function. The model is also based on finite volume method using HLLC (Harten, Lax and van Leer(1983)) numerical flux. The model was applied to experimental data of a bed degradation and aggradation with armouring and downstream fining. It shows that the model has ability to reproduce the process of bed degradation and aggradation with aromouring and downstream fining, but the more improvement is needed to predict reasonable accuracy.
\end{abstract}

Key Words : numerical model, gravel transport, gravel/sand grain size distributions

\section{1. はじめに}

近年，治水と環境とが調和した川づくりが求められて いる. 河川の環境保全を目的に様々な河川で自然再生事 業1),2,3)が取り組まれており，このような河川の再自然化 のための考え方や適用例の取りまとめ)も行われている。

河川の再自然化のためには, 各河川が有する自立形成 機能を把握し，その特性に応じて河道管理や環境保全対 策を行う必要がある. 河道形成流量と河床材料の代表粒 径と安定な河道断面形状の川幅，水深・河床勾配との関 係5,(6), は，その評価方法の一つであり実務での検討 ${ }^{2}$ に 用いられつつある。

このような経験式に加え，評価に有用な様々な数值モ デルが開発されている8,9,10,111,12). 代表的なモデルには, 移動一般座標系を用いて流路の形状を追跡する平面2次 元解析モデル ${ }^{8}$ や，斜面崩落モデルを導入し河床と河岸 の侵食を一連のプロセスとして取り扱う平面 2 次元解析 モデル9，石碩河川を対象とした平面2次元河床変動モデ ル10)，非平衡流砂量式 ${ }^{11}$ や準3次元モデル12)を用いた河 床変動モデル，などがある．各河川が有する自立形成機
能を把握するためには，出水や河川改修が河床や河道に 及ぼすインパクト，すなわち出水や河川改修によって生 じる(1) 混合粒径河床での河床変動, (2) 出水時の流量, 河床勾配, 構成する河床材料などに応じて生じる砂州の 形成や発達, それに伴う流路の変動, (3)流砂の分級, (4) 河岸侵食, さらには(5) 出水規模や履歴, 河床材料 に応じた安定河床・河道の形成などの非常に複杂倠な一連 のプロセスを的確に評価できることが求められるが，上 記の(1)〜(5)の全てを満たすモデルは著者らの知る限り 存在しない. この要因の一つとして, 混合河床を取り扱 う上で最も基本となる粒径別の流砂の連続の式の離散化 が挙げられる，例えば, 最も単純な1次元モデルであっ ても常・射混在流下では粒度比率の総和が1 とならない 場合やアーマーコートの形成を伴う河床低下では粒度比 率が0〜1の範囲に収まらないなどの問題が生じ，その抜 本的な解決方法がないのが実状である ${ }^{13)}$.

本研究は，以上のような背景を踏まえ，上記の $(1) \sim$ (5)の全てを満たし，河川の自立形成機能を生かした川づ くりに有用な情報を提供できる平面2次元混合砂碩河 床・流路変動モデルの構築を最終的な目標にしている. ここでは, その第一歩として, 混合砂礫河川を対象に, 
有限体積法と近似リーマン解法を用い，上記の(1)と(3) を満たす平面2次元河床変動モデルを新たに構築した. 次に, 河床低下によるアーマリングや, 常射流混在下で の河床材料の細粒化を伴う河床上昇の実験結果に適用し, その予測精度を検証した。

\section{2. 基礎方程式}

\section{（1）流れの基礎方程式}

流れの基礎方程式は2次元浅水流方程式である. Uを

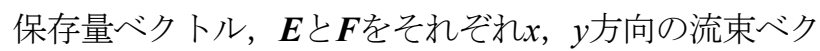
トルおよびをを発生項・消滅項ベクトルとすると, 連続 の式と $x, y$ 方向の運動量保存の式は式(1)で表される.

$$
\begin{gathered}
\frac{\partial \boldsymbol{U}}{\partial t}+\frac{\partial \boldsymbol{E}}{\partial x}+\frac{\partial \boldsymbol{F}}{\partial y}+\boldsymbol{S}_{1}+\boldsymbol{S}_{2}=\mathbf{0} \\
\boldsymbol{U}=\left(\begin{array}{lll}
h & u h & v h
\end{array}\right)^{T} ; \boldsymbol{E}=\left(\begin{array}{lll}
u h & u^{2} h+\frac{1}{2} g h^{2} & u v h
\end{array}\right)^{T} ; \\
\boldsymbol{F}=\left(\begin{array}{llll}
v h & u v h & v^{2} h+\frac{1}{2} g h^{2}
\end{array}\right)^{T} ; \boldsymbol{S}_{1}=\left(\begin{array}{lll}
0 & -g h S_{0 x} & -g h S_{0 y}
\end{array}\right)^{T} ; \\
\boldsymbol{S}_{2}=\left(\begin{array}{lll}
0 & g h S_{f x} & g h S_{f y}
\end{array}\right)^{T}
\end{gathered}
$$

ここに, $h=$ 水深, $u, v=x, y$ 方向の流速, $g=$ 重力加速度, $S_{\mathrm{ox}}, S_{\mathrm{o} y}=x, y$ 方向の地盤勾配, $z_{b}=$ 河床高, $S_{f k}, S_{f y}=x, y$ 方向の摩擦勾配である. 河床および摩擦勾配はそれぞれ 式(2)および(3)で計算される。

$$
\begin{gathered}
S_{0 x}=-\partial z_{b} / \partial x ; S_{0 y}=-\partial z_{b} / \partial y \\
S_{f x}=1 / \phi^{2} \cdot u \sqrt{u^{2}+v^{2}} ; S_{f y}=1 / \phi^{2} \cdot v \sqrt{u^{2}+v^{2}}
\end{gathered}
$$

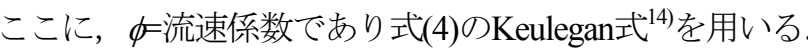

$$
\phi=2.5 \ln \left(11 h / k_{s}\right)
$$

ここに, $k_{s}=$ 粗度高さであり, 平坦床の場合は式(5)の関 係から求める.

$$
k_{s}=n_{k} D_{s 90}
$$

ここに， $D_{s 90}=$ 河床表層の累加分率 $90 \%$ 粒径である. また $n_{k}=$ 係数 $(2 \sim 3.5)$ である.

\section{（2）混合砂礫河床変動の基礎方程式}

混合砂制河床の河床変動の基礎方程式は，全粒径と交

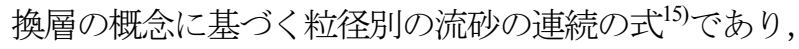
それぞれ式(6)と式(7)で表される. 図-1に定義図を示寸.

$$
\begin{gathered}
\left(1-\lambda_{b}\right) \frac{\partial z_{b}}{\partial t}+\frac{\partial\left(q_{B T x}\right)}{\partial x}+\frac{\partial\left(q_{B T y}\right)}{\partial y}=0 \\
\left(1-\lambda_{b}\right)\left[f_{I j} \frac{\partial\left(z_{b}-L_{a}\right)}{\partial t}+\frac{\partial}{\partial t}\left(L_{a} F_{j}\right)\right]+\frac{\partial\left(q_{B j x}\right)}{\partial x}+\frac{\partial\left(q_{B j y}\right)}{\partial y}=0
\end{gathered}
$$

ここに, $\lambda_{b}=$ 河床材料の空隙率, $q_{B T x}, q_{B T y}=x, y$ 方向の流 砂量, $j=j$ 番目の土砂の粒径を表寸添字, $f_{I j}=$ 交換層と貯 留層との境界での粒度比率, $L_{a}=$ 交換層の厚さ, $F_{j}=$ 交換 層での粒度比率， $q_{B T x}, q_{B T y}=x, y$ 方向の全流砂量である. 式(6)と式(7)より，式(8)のような交換層での粒度比率 $F_{j}$ の時間変化に関する方程式が得られる.

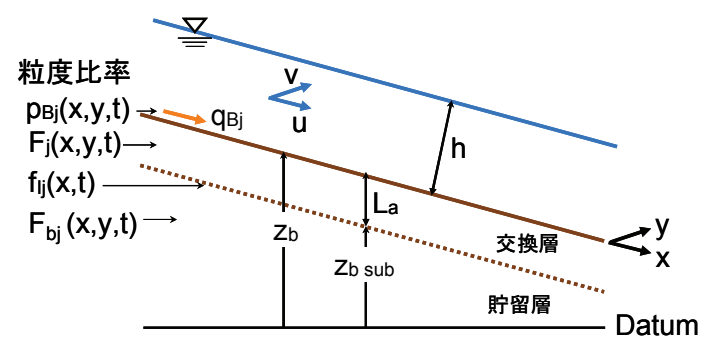

図-1＼cjkstart流れと河床変動の定義図

$$
\begin{aligned}
& \left(1-\lambda_{b}\right)\left[L_{a} \frac{\partial F_{j}}{\partial t}+\left(F_{j}-f_{I j}\right) \frac{\partial L_{a}}{\partial t}\right]= \\
& -\left\{\frac{\partial\left(q_{B x y}\right)}{\partial x}+\frac{\partial\left(q_{B, j}\right)}{\partial y}-f_{I j}\left(\frac{\partial\left(q_{B T x}\right)}{\partial x}+\frac{\partial\left(q_{B T y}\right)}{\partial y}\right)\right\}
\end{aligned}
$$

$x, y$ 方向の流砂量は, 主流方向の全流砂量 $q_{B T}$ 之粒径別 流砂量 $q_{B i}$ とを用いると式(9)のように表される.また, 全流砂量 $q_{B T}$ と粒径別流砂量 $q_{B i}$ には式(10)の関係がある.

$$
\begin{gathered}
q_{B x j}=q_{B j} \cos \theta, \quad q_{B y j}=q_{B j} \sin \theta \\
q_{B T x}=q_{B T} \cos \theta, \quad q_{B T y}=q_{B T} \sin \theta \\
\cos \theta=u / \sqrt{u^{2}+v^{2}}, \quad \sin \theta=v / \sqrt{u^{2}+v^{2}} \\
q_{B T}=\sum_{j=1}^{N} q_{B j}
\end{gathered}
$$

ここに, $N=$ 粒径の分割数である. 粒径別流砂量 $q_{B i}$ の算 定には，(1遮蔽効果に修正エギアザロフ式を適用した芦 田・道上 ${ }^{16)}$ の流砂量式と，(2)喼間に存在する砂の影響を 考慮したWilcok and Crowe ${ }^{17)} の$ 流砂量式を用いた。 芦 田・道上の粒径別流砂量式を式(11)に，Wilcok and Crowe の流砂量式を式(12)に示す.

(1)芦田・道上式

$$
\begin{aligned}
& q_{B j}=F_{j} \cdot 17 \cdot \sqrt{s g D_{j}^{3}} \tau_{*_{j}}^{3 / 2}\left(1-\tau_{*_{c j}} / \tau_{*_{j}}\right)\left(1-u_{*_{c j}} / u_{*}\right) \\
& \frac{\tau_{*_{c j}}}{\tau_{*_{s c g}}}=\left\{\begin{array}{cc}
0.843\left(D_{j} / D_{s g}\right)^{-1} & D_{j} / D_{s g} \leq 0.4 \\
{\left[\log _{10} 19 / \log _{10}\left(19 D_{j} / D_{s g}\right)\right]^{2}} & D_{j} / D_{s g}>0.4
\end{array}\right.
\end{aligned}
$$

(2)Wilcok and Crowe式

$$
\begin{gathered}
q_{B j}=F_{j} \cdot \frac{u_{*}^{3}}{s g} \cdot G\left(\varphi_{i}\right) ; G\left(\varphi_{j}\right)=\left\{\begin{array}{cc}
0.002 \varphi_{j}^{7.5} & \varphi_{j}<1.35 \\
14\left(1-0.894 / \varphi_{j}^{0.5}\right)^{4.5} & \varphi_{j} \geq 1.35
\end{array}\right. \\
\varphi_{j}=\frac{\tau_{* s g}}{\tau_{* s s g}}\left(D_{j} / D_{s g}\right)^{-b}, b=0.67 /\left\{1+\exp \left(1.5-D_{j} / D_{s g}\right)\right\} \\
\tau_{* s g g}=0.021+0.015 \exp \left(-20 F_{s}\right), \quad \tau_{* g}=u_{*}^{2} / s g D_{s g}
\end{gathered}
$$

ここに, $D_{j}=$ 交換層でのj番目の土砂の粒径， $D_{\mathrm{sg}}=$ 交換層 での平均粒径, $\tau_{* j}=D_{j}$ に対応寸る無次元掃流力, $u_{*}=$ 摩擦 速度 $\left(=\left(g h S_{\mathrm{f}}\right)^{0.5}\right), \quad S_{\mathrm{f}}=\left(S_{\mathrm{fx}}{ }^{2}+S_{\mathrm{fy}}{ }^{2}\right)^{0.5}, \quad \tau_{*_{\mathrm{scg}}}=D_{s g}$ に対応する限界 無次元掃流力, $\tau_{\text {*sg }_{\mathrm{sg}}}=$ 磪間に存在する砂の影響を考慮した refferenceシールズ数, $F_{s}=$ 交換層の砂の粒度比率である. 交換層厚 $L_{a}$ は式(13)より算定する.

$$
L_{a}=n_{a} D_{90}
$$

ここに $n_{a}$ は係数である. 交換層と貯留層との境界での粒 度比率 $f_{I j}$ はHoey and Ferguson ${ }^{18)}$ が提案する式(14)を用いた。

$$
f_{I j}=\left\{\begin{array}{cc}
F_{b j}(z)_{z=z_{b}-L_{a}} & \partial z_{b} / \partial t<0 \\
a F_{j}+(1-a) p_{B j} & \partial z_{b} / \partial t \geq 0
\end{array}\right.
$$

ここに $F_{b}(z)=$ 貯留層, $p_{B \mathrm{j}}\left(=q_{\mathrm{B} \mathrm{j}} / q_{\mathrm{BT}}\right)=$ 流砂量の粒度比率であ 
る. 式(14)では，掃流砂の粒度が河床上昇時に堆積層へ 取り残される砂碩に及ぼす影響が考慮されており，その 影響は交換層と流砂量の粒度の重み係数 $a(=0 \sim 1)$ で表さ

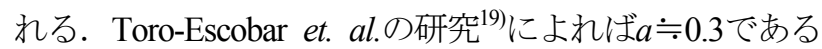
ことが分っている. なお， $a=1$ の場合，堆積層へ取り残 される砂碩は交換層の粒度となり平野 ${ }^{15)}$ の式と一致する.

\section{3. 数值モデルの概要}

流れと混合砂礫河床変動の基礎方程式の離散化は，い ずれも有限体積法(FVM) に基づき行った。計算領域を 分割した微小領域セル $i$ 検査体積 $\Omega_{i}$ とし, 式(1), 式(6) および式(8)を有限体積法に基づき離散化すると，それぞ れ式(15), 式(16)および式(17)が得られる，なお，時間積 分にはEulerの陽解法を用いた。

$$
\begin{aligned}
& \boldsymbol{U}_{i}^{t+1}=\boldsymbol{U}_{i}^{t}- \frac{\Delta t}{A_{i}} \sum_{k=1}^{N}\left(\boldsymbol{F}_{\boldsymbol{n}}^{*} \cdot \boldsymbol{n}\right)_{k} d L_{k}-\frac{\Delta t}{A_{i}} \int_{V}\left(\boldsymbol{S}_{1}+\boldsymbol{S}_{2}\right) d V \\
& z_{b i}^{t+1}=z_{b i}^{t}-\frac{1}{1-\lambda_{b}} \frac{\Delta t}{A_{i}} \sum_{k=1}^{N}\left(q_{B T}^{*} \cdot \boldsymbol{n}\right)_{k} d L_{k} \\
& F_{j i}^{t+1}=F_{j i}^{t}-\frac{1}{\left(1-\lambda_{b}\right) L_{a i}} \frac{\Delta t}{A_{i}} \cdot \\
&\left(\sum_{k=1}^{N}\left(q_{B F j}^{*} \cdot \boldsymbol{n}\right)_{k} d L_{k}-f_{I j i} \sum_{k=1}^{N}\left(q_{B F T}^{*} \cdot \boldsymbol{n}\right)_{k} d L_{k}\right)- \\
& \frac{1}{L_{a i}}\left(F_{j i}-f_{I j i}\right) \frac{\partial L_{a i}}{\partial t} \Delta t
\end{aligned}
$$

ここに, $\boldsymbol{U}_{i}=$ セル $i$ での $\boldsymbol{U}$ の平均值, $A_{i}=$ セル $i$ の面積, $t=$ 時間に対する添字, $k=$ セル $i$ を構成するセル境界線に 対する添字, $N_{e}$ =セルを構成するセル境界線の総数, $\Delta t=$ 時間の刻み幅, $L_{k}=k$ 番目のセル境界線の長さ， $\left(\boldsymbol{F}_{n}\right.$ ・ $\boldsymbol{n})_{k}{ }_{k}=k$ 番目のセル境界線を流入出する流れの数值流束, $\boldsymbol{S}_{2 i}=$ セル $i$ での $\boldsymbol{S}_{2}$ の平均值, $z_{b l}$ =セル $i$ での河床高, $\left(q B_{T} \cdot \boldsymbol{n}\right)^{*}{ }_{k}=k$ 番目のセル境界線を流入出する河床変動の 数值流束, $F_{j}=$ セル $i$ での交換層での粒度比率, $L_{a l}=$ セル $i$ での交換層厚, $f_{I j}=$ セル $i$ での交換層と貯留層との境界 での粒度比率, $\left(q B_{F T} \cdot \boldsymbol{n}\right)^{*}{ }_{k}=k$ 番目のセル境界線を流入 出する粒度比率の数值流束, $\left(q B_{F j} \cdot \boldsymbol{n}\right)_{k}{ }_{k}=k$ 番目のセル 境界線を流入出する粒径 $j$ の土砂の粒度比率の数值流束 である．なお，式(17)中の $\partial L_{a i} / \partial t ・ \Delta t$ は，時間変化量は 大きくは変化しないと考え，一つ前の時間の交換層厚の 変化量 $L_{a i}{ }^{t} L_{a i}^{t-1}$ を用いた.

流れの数值流束 $\left(\boldsymbol{F}_{n} \cdot \boldsymbol{n}\right)^{*}{ }_{k}$ には, 近似リーマン解法の一 つで HLL(Harten, Lax and van Leer)の数值流束より数值拡 散が小さい HLLC(Harten, Lax,van Leer Contact) ${ }^{20)}$ を用い た. HLLC の数值流束は式(18)で表される.

$$
\begin{gathered}
\boldsymbol{F}_{\boldsymbol{n}}^{*} \cdot \boldsymbol{n}= \begin{cases}\left(\boldsymbol{F}_{\boldsymbol{n}} \cdot \boldsymbol{n}\right)_{L} & \text { if } S_{L} \geq 0 \\
\left(\boldsymbol{F}_{\boldsymbol{n}} \cdot \boldsymbol{n}\right)_{*_{L}} & \text { if } S_{L}<0 \leq S_{M} \\
\left(\boldsymbol{F}_{\boldsymbol{n}} \cdot \boldsymbol{n}\right)_{*_{R}} & \text { if } S_{M} \leq 0<S_{R} \\
\left(\boldsymbol{F}_{\boldsymbol{n}} \cdot \boldsymbol{n}\right)_{R} & \text { if } S_{R} \leq 0\end{cases} \\
\left(\boldsymbol{F}_{\boldsymbol{n}} \cdot \boldsymbol{n}\right)_{*_{L}}=\left(\boldsymbol{F}_{\boldsymbol{n}} \cdot \boldsymbol{n}\right)_{L}+S_{L}\left(\boldsymbol{U}_{*_{L}}-\boldsymbol{U}_{L}\right) \\
\left(\boldsymbol{F}_{\boldsymbol{n}} \cdot \boldsymbol{n}\right)_{*_{R}}=\left(\boldsymbol{F}_{\boldsymbol{n}} \cdot \boldsymbol{n}\right)_{R}+S_{R}\left(\boldsymbol{U}_{*_{R}}-\boldsymbol{U}_{R}\right)
\end{gathered}
$$

$$
\boldsymbol{U}_{*^{\prime} L / R}=h_{L / R}\left(\frac{S_{L / R}-u_{n L / R}}{S_{L / R}-S_{M}}\right)\left(\begin{array}{c}
1 \\
S_{M} n_{x}-u_{t L / R} n_{y} \\
S_{M} n_{y}+u_{t L / R} n_{x}
\end{array}\right)
$$

ここに, $u_{n}=u n_{x}+v n_{y}, u_{t}=-u n_{y}+v n_{x}$ である. 式(18)中の $S_{L}$ と $S_{R}$ は，七ル境界線の $L$ 側と $R$ 側， $S_{\mathrm{M}}$ はそれらの中間 の特性速度あり，それぞれ式(19)で定義される。

$$
\begin{gathered}
S_{L}=\left\{\begin{array}{cc}
u_{n R}-2 c_{R} & \text { if } h_{L}=0 \\
u_{n L}-\sqrt{\frac{g\left(h_{*}+h_{L}\right) h_{*}}{2 h_{L}}} & \text { if } 0<h_{L}<h_{*} \\
\min \left(u_{n L}-c_{L}, U_{*}-c_{*}\right) & \text { if } h_{*} \leq h_{L}
\end{array}\right. \\
S_{R}=\left\{\begin{array}{cc}
u_{n L}+2 c_{L} & \text { if } h_{R}=0 \\
u_{n R}-\sqrt{\frac{g\left(h_{*}+h_{R}\right) h_{*}}{2 h_{R}}} & \text { if } 0<h_{R}<h \\
\max \left(u_{n R}+c_{R}, U_{*}+c_{*}\right) & \text { if } h_{*} \leq h_{R}
\end{array}\right.
\end{gathered}
$$$$
S_{M}=U_{*}
$$

また， $c=(g h)^{0.5}$ であり，U*および * $_{*}$ ，式(20)で求める.

$$
\begin{gathered}
U_{*}=\left(u_{n L}+u_{n R}\right) / 2+c_{L}-c_{R} \\
h_{*}=\left\{2\left(c_{L}+c_{R}\right)+\left(u_{n L}-u_{n R}\right)\right\}^{2} / 16 g
\end{gathered}
$$

空間微分を含む発生項べクトル $S_{1}$ については，数值 流束と同様に特性速度に基づき風上化 ${ }^{20)}$ を行い, 式(21) のように離散化を行った。

$$
-\frac{\Delta t}{A_{i}} \int_{V} \boldsymbol{S}_{1} d V=-\frac{\Delta t}{A_{i}} \sum_{k=1}^{N}\left(\boldsymbol{S}_{1 \boldsymbol{n}}^{*} \cdot \boldsymbol{n}\right)_{k} d L_{k}
$$

ここに, $\boldsymbol{S}_{1 n}{ }^{*} \cdot \boldsymbol{n}$ は発生項ベクトル対応する数值流束で あり，式(22)〜式(24)で表される.

- $S_{L} \geqq 0$ の場合 :

$$
\begin{gathered}
\left(\boldsymbol{S}_{1 \boldsymbol{n}}^{*} \cdot \boldsymbol{n}\right)_{L}=\mathbf{0} \\
\left(\boldsymbol{S}_{1 \boldsymbol{n}}^{*} \cdot \boldsymbol{n}\right)_{R}=g\left\{\frac{\left(h_{L}+h_{R}\right)}{2}\left(\left(\boldsymbol{S}_{1} \cdot \boldsymbol{n}\right)_{R}-\left(\boldsymbol{S}_{1} \cdot \boldsymbol{n}\right)_{L}\right)\right\}
\end{gathered}
$$

- $S_{L}<0<S_{R}$ の場合 :

$$
\begin{aligned}
& \left(\boldsymbol{S}_{1 \boldsymbol{n}}^{*} \cdot \boldsymbol{n}\right)_{L}=-\frac{S_{L}}{S_{R}-S_{L}}\left[g\left(\frac{\left(h_{L}+h_{R}\right)}{2}\left(\left(\boldsymbol{S}_{1} \cdot \boldsymbol{n}\right)_{R}-\left(\boldsymbol{S}_{1} \cdot \boldsymbol{n}\right)_{L}\right)\right\}\right] \\
& \left(\boldsymbol{S}_{1 \boldsymbol{n}}^{*} \cdot \boldsymbol{n}\right)_{R}=\frac{S_{R}}{S_{R}-S_{L}}\left[g\left\{\frac{\left(h_{L}+h_{R}\right)}{2}\left(\left(\boldsymbol{S}_{1} \cdot \boldsymbol{n}\right)_{R}-\left(\boldsymbol{S}_{1} \cdot \boldsymbol{n}\right)_{L}\right)\right\}\right](23)
\end{aligned}
$$

- $S_{R} \leqq 0$ の場合 :

$$
\begin{gathered}
\left(\boldsymbol{S}_{1 \boldsymbol{n}}^{*} \cdot \boldsymbol{n}\right)_{L}=g\left\{\frac{\left(h_{L}+h_{R}\right)}{2}\left(\left(\boldsymbol{S}_{1} \cdot \boldsymbol{n}\right)_{R}-\left(\boldsymbol{S}_{1} \cdot \boldsymbol{n}\right)_{L}\right)\right\} \\
\left(\boldsymbol{S}_{1 \boldsymbol{n}}^{*} \cdot \boldsymbol{n}\right)_{R}=\mathbf{0}
\end{gathered}
$$

ここに, $\boldsymbol{S}_{1 n}{ }^{*} \cdot \boldsymbol{n}=\left(0, z_{b} n_{x}, z_{b} n_{y}\right)^{\mathrm{T}}$ である. 消滅項ベクト ル $\boldsymbol{S}_{2}$ については, 計算セルの重心で定義される保存量 $\boldsymbol{U}$ に基づき計算を行う。

河床変動の数值流束 $\left(q B_{T} \cdot \boldsymbol{n}\right)^{*}{ }_{k}$ と粒度比率の数值流束 $\left(q B_{F T} \cdot \boldsymbol{n}\right)_{k}^{*},\left(q B_{F j} \cdot \boldsymbol{n}\right)_{k}^{*}$ にはそれぞれ式(25)と式(26), 式 (27)を用いた. 式(25)と(26)は式(6)の左辺第 2, 3 項と式 (8)中の右辺第 3, 4 項を離散化するための数值流束であ るので一致したものを用いることが妥当であるが，その 場合, 新しい時間ステップの粒度比率 $F_{j}$ が $\sum F_{j}=1$ や 0 $\leqq F_{j} \leqq 1$ が満たされないなどの問題が生じ，各粒度比率 の再配分，時間ステップの修正などを行うなど，最終的 には何らかの処理が必要になる. 本研究では, これらを 避けるために, 各微分方程式が双曲型の偏微分方程式で 
あることを踏まえ式(25) 式(27)の数值流束を用いた. よ り一般的な粒度比率と河床高の影響を考慮した数值流束 のあり方については今後の課題としたい.

$$
\begin{gathered}
q_{B T}^{*} \cdot \boldsymbol{n}=\sum_{j=1}^{N} q_{B j}^{*} \cdot \boldsymbol{n} \\
q_{B j}^{*} \cdot \boldsymbol{n}=0.5\left\{\left(q_{B j L L}+q_{B j n R}\right)-0.5\left|\frac{q_{B j n R}-q_{B j n L}}{z_{b R}-z_{b L}}\right|\left(z_{b R}-z_{b L}\right)\right\} \\
q_{B F T}^{*} \cdot \boldsymbol{n}=\sum_{j=1}^{N} q_{B F j}^{*} \cdot \boldsymbol{n} \\
q_{B F j}^{*} \cdot \boldsymbol{n}=0.5\left\{\left(q_{B j n L}+q_{B j n R}\right)-0.5\left|\frac{q_{B j n R}-q_{B j n L}}{F_{j R}-F_{j L}}\right|\left(F_{j R}-F_{j L}\right)\right\} \\
\text { こに, } q_{B j h}=q_{B j x} \cdot n_{x}+q_{B j j} \cdot n_{y} \text { である. }
\end{gathered}
$$

貯留層での粒度比率 $F_{b j}(z)$ について，図-2 に示すよ うに貯留槽と基岩層との間を $M$ 個のソロバン格子 ${ }^{21)}$ で 分割し, 各格子点での粒度比率 $F_{b}$ を次のように求めた. ただし，ソロバン格子の格子点の再配置については，各 格子幅が等間隔となるように行った。

(1) 貯留槽の最上面の座標を $\mathrm{z}^{\mathrm{t}+1}=z_{b}{ }^{\mathrm{t}+1}-L_{a}{ }^{\mathrm{t}+1}$ に更新する.

(2) $\mathrm{z}^{\mathrm{t}+1}=z_{b}{ }^{\mathrm{t}+1}-L_{a}{ }^{\mathrm{t}+1}$ での粒度比率を更新する.

(3) 河床が上昇する場合 : $F_{b j}(z)=f_{\mathrm{Ij}}$

(4) 河床が低下寸る場合 : $F_{b j}(z)=F_{b j}\left(z_{b}{ }^{\mathrm{t}+1}-L_{a}{ }^{\mathrm{t}+1}\right)$

(5) $\mathrm{z}^{\mathrm{t}+1}$ と基岩層 $\left(\mathrm{z}_{\text {base }}\right)$ との距離から等間隔になるよう格 子間距離 $d z$ を求める.

(6) $d z$ を用いて格子を再配置する. $\mathrm{z}^{\mathrm{t}+1}$ と基岩層 $\left(\mathrm{z}_{\text {base }}\right)$ と の間の格子点については, $z$ 軸方向に時間 $t$ の $F_{b j}(z)$ を用いて線形補間することで $F_{b j}{ }^{t+1}(z)$ に更新する.

計算セルには三角形 $\left(N_{e}=3\right)$ の非構造格子を用いた。 ま た, 時間の刻み幅は, クーラン型の安定条件と消滅項を 考慮した安定条件を用いた ${ }^{22}$.

\section{4. モデルの適用}

本モデルを(1)粗粒化を伴う河床低下 ${ }^{23}$ および(2)細粒化 を伴う河床上昇の実験 ${ }^{24)} に$ 適用し，その基本性能の検証 を行った。解析は，流砂量式に芦田・道上式尚を用いた AM-model とWilcok and Crowe式 ${ }^{17)}$ 用いたWC-modelに 加え, 従来のモデルとの比較を目的に, 流砂量式に芦 田・道上式 ${ }^{16)}$, 交換層と貯留層との境界での粒度比率 $f_{f j}$

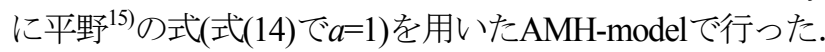

\section{（1）粗粒化を伴う河床低下の実験 ${ }^{23)}$ への適用}

実験は，幅 $0.8(\mathrm{~m}) ，$ 長さ20(m)，初期の河床勾配 $1 / 100$ の直線水路で行われており，河床には図-3に示寸粒度分 布を持つ混合砂砂が敷き詰められている．上流端からは 流量 $Q=0.0314\left(\mathrm{~m}^{3} / \mathrm{s}\right)$ の水を流入させ, armouringを伴う河 床低下を生じさせている，測定項目は水位，河床高およ び粒度分布である。

解析領域を160個の三角セルで分割し，流れの上下流 端の境界条件には流量と水位を, 河床変動の境界条件に

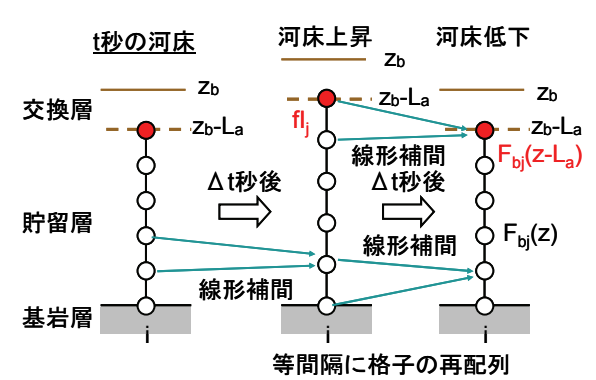

図-2 貯留層での粒度比率 $F_{b j}(z)$ の取り扱い

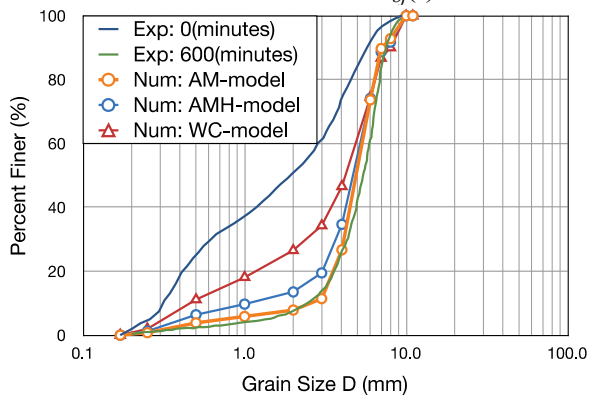

図-3 実験で用いた粒度分布と解析結果

は上流端に流砂量 $0\left(\mathrm{~m}^{3} / \mathrm{s}\right)$ を，下流端には河床高を与えた。 計算にはパラメータ $n_{\mathrm{a}}, \lambda_{\mathrm{b}}, n_{k}, a$ の值が必要となる. それぞれのパラメータを変化させ感度解析を行った結果, AM-model, WC-model では $n_{\mathrm{a}}=1.0, \quad \lambda_{\mathrm{b}}=0.4, n_{k}=3.5$, $a=0.28$, AMH-modelでは $n_{\mathrm{a}}=3.5, \quad \lambda_{\mathrm{b}}=0.4, n_{k}=3.5, \quad a=1.0$ の 場合に実測結果との整合性が高いことが確認された。一 方，WC-modelではパラメータを変化させても河床低下 の経過時間変化を再現することがはできず，いずれも定 性的には後述する結果と同様な結果となった。

図-4は，上流端から7(m)，10(m)，13(m)地点での河床 低下量の経時変化について, 解析結果と実駼值を示した ものである. 実験值では(1) 0 100分では河床が低下し， (2) その割は徐々に低下し，100分以降はぼ0となり，河 床が armouringされるプロセスが確認できる．AM と AMH-modelでは実験で観測されたプロセスを的確にと らえており, 河床低下を十分な精度で再現していること がわかる，一方，WC-modelではAM-modelに比べ河床低 下に長い時間が必要であり，このようなプロセスは再現 できはいないが，時間の経過とともに河床高は実験值に 近づくことがわかる.

図-3は，通水600分後の粒度分布の解析結果と実験值 との比較を示したものである。これより，(1) AM， AMH, WC-modelのいずれも粗粒子成分の粒度比率は再 現していること，(2) WC-modelでは，上述のように河床 低下プロセスを再現できないために，実験值よりも河床 材料の粒径が細かく予測されること，(3) 一方，AMと AMH-modelについては分布は概ね再現しており，特に, AM-modelは, AMH-modelに比べ細粒子成分までも適切 に評価していること，などが確認できる。このように， AM-modelであれば啇切なパラメータ值を用いることで, 河床低下によるarmouringを適切に再現できることが確認 された．なお，いずれのモデルも粒度比率が 0 ～ 1 範囲 に収まらないなどの問題は発生しなかった。 


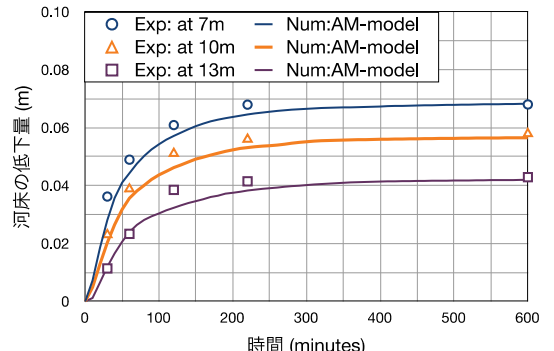

図-4 河床低下量の経過時変化 (左

\section{（2） 細粒化を伴う河床上昇の実験 ${ }^{24)}$ への適用}

本モデルをRun1の実験に適用した．実験は幅0.305(m), 長さ50(m), 初期の河床勾配1/500のコンクリート製の直 線水路で行われている. 上流端から流量 $Q=0.049\left(\mathrm{~m}^{3} / \mathrm{s}\right)$ の 水と図-5に示寸粒度分布を持つ混合砂碩が $11.3(\mathrm{~kg} / \mathrm{min})$ で給砂されており，下流端は水位が $0.4(\mathrm{~m})$ の一定值と なっている．測定項目は水位，河床高，粒度分布である。

解析領域を224個の三角セルで分割し，流れの上下流 端の境界条件には流量と水位を, 河床変動の境界条件に は上流端に流砂量を，下流端には河床高を与えた。パラ メータ值は $n_{\mathrm{a}}=1.0, \lambda_{\mathrm{b}}=0.3, n_{k}=2.0, a=0.3$ を用いた。 な お，AMH-modelでは計算終了時間まで計算を継続がで きなかった. AMとWC-modelで安定した計算が行えたこ とを踏まえると, これはAMH-modelが貯留層に堆積す る砂䃇を適切に評価できなかったためと考えられる，以 下ではAMとWC-modelの結果のみを示す。

図-6は，各時間での河床高縦断図と通水開始から5 10 時間の間で観測された表層(交換層)での $10 \%, 30 \%$, $50 \% ， 70 \% ， 90 \%$ 粒径 $D_{10} ， D_{30} ， D_{50} ， D_{70} ， D_{90}$ の縦断変 化の実験值と解析結果との比較を行ったものである. な お，粒径の解析結果については通水から10時間後の結果 を示している.これより，(1) いずれのモデルも堆砂フ ロントが進行するプロセスや流下とともに細粒化するプ ロセスを再現していること，(2) 水面形から明らかなよ うに跳水が発生しているにもかかわらず，安定した計算 が行えていること，(3) いずれのモデルも流入部付近と フロント部分で差異はあるが，河床高の実験結果を概ね 再現していること，(4) 一方で, 粒径の縦断変化につい ては， $D_{90}$ の縦断変化は再現しているものの， $D_{30} \sim D_{70}$ に ついては過大評価していること，などがわかる．このよ うな誤差が生じた理由を以下で考察する。

図-7はWC-modelで数 $a=0.5$ とした場合の河床高縦断図 と表層での $D_{10}, D_{30}, D_{50}, D_{70}, D_{90}$ の縦断変化である. これより, $a=0.3$ の結果に比べ，(1)上流側で河床高は小 さく, 堆砂フロントの進行も早く評価され予測精度が低 下していること，(2)一方で粒径の縦断変化は $D_{90}$ の再現 精度は劣るものの，他の粒度の縦断変化については再現 性が改善されること，などが確認できる．係数aは掃流 砂の粒度が河床上昇時に堆積層へ取り残される砂礫に及 ぼす影響の度合いを表わ寸パラメータであり，その総合 的な影響は河床高に表れると考えられる. 従って, Toro-Escobar et. al. ${ }^{19)} の a \fallingdotseq 0.3$ 用いることで, 両モデル

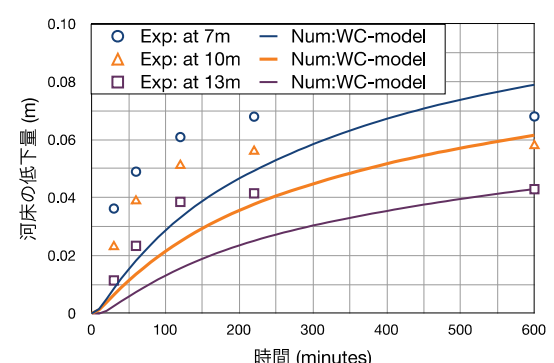

AM-model, 中: AMH-Model, 右:WC-model)

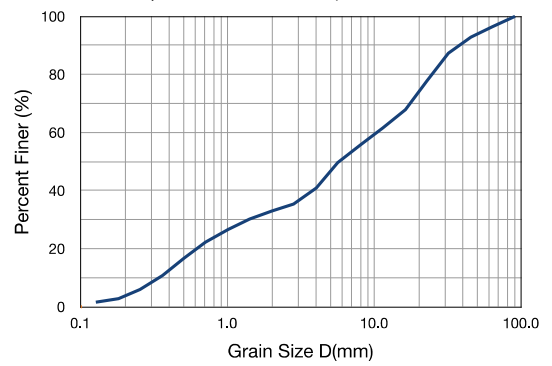

図-5 実験と解析の粒度分布

ともに河床高を再現できたと考えられる，一方で，aを 変化させることで粒度分布の予測精度が変化することを 踏まえると， $a$ は流れ，掃流砂の粒度や河床の状態など によって変化すると考えられる，そのため，aを一定值 とした本モデルでは粒度分布に誤差が生じたと考えられ る.この詳細については今後の課題としたい.

\section{5. おわりに}

本研究では，有限体積法と近似リーマン解法を用いて， 混合砂碩河川を対象とした平面2次元河床変動モデルを 新たに構築し, 河床低下による 下での河床材料の細粒化を伴う河床上昇の実験結果に適 用し，その予測精度を検証した。 その結果，本モデルは， 従来のモデルに比べ高い精度で，同現象を再現すること ができるが，交換層と貯留層での粒度比率の求め方に課 題が残ることがわかった. 今後はこの点について改善し たいと考えている.

謝辞 : 本研究は科学研究費補助金若手研究 $\mathrm{B}$ (課題番号: 21760388, 研究代表者 : 重枝未玲)の助成を受け実施し たものである．本研究を遂行するに当り，本学学部4年 生上田達郎君にはデー夕整理等で多大な協力を得た。こ こに記して感謝の意を表します。

\section{参考文献}

1）長谷川和義，藤田将輝，渡邊康玄，桑村貴志 : 標津川旧蛇 行通水時の堰をともなう分岐流量配分比に関する研究，水 工学論文集, 第47巻, pp.529-534, 2003.

2）大賀洋一，森脇孝弘，桝井芳樹，福岡捷二 : 江の川上流部 における治水と環境とが調和した河道断面形に関する評価, 河川技術論文集，第17巻，pp.137-142，2011.

3）松田浩一, 須藤達美, 内堀寿美男, 大島秀則, 清水義彦, 


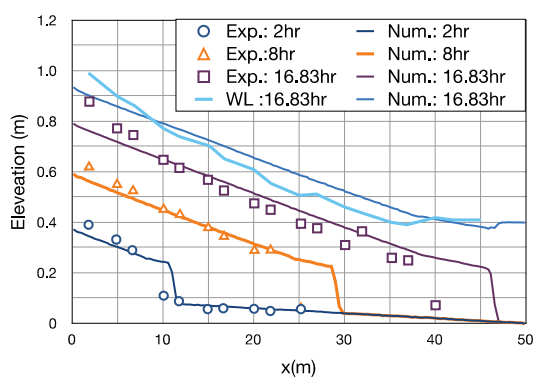

(a) 河床高 (左 : AM-model, 右:WC-model)
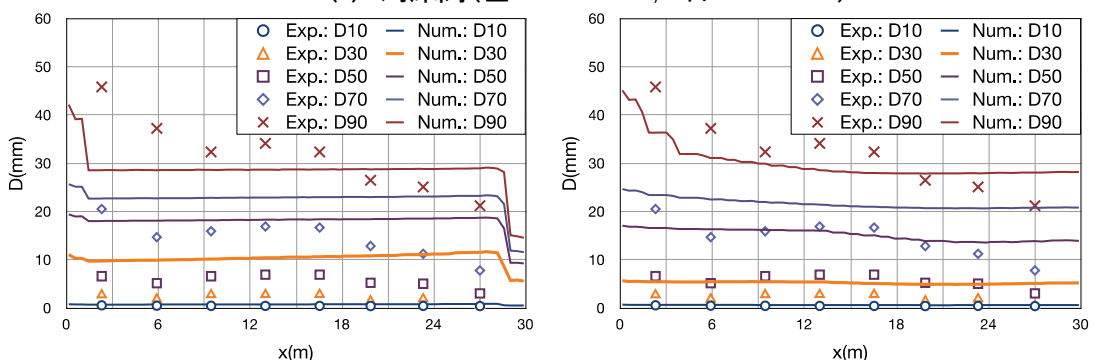

(b) 粒径 (左: AM-model, 右:WC-model)

図-6 河床と粒径の縦断変化 $(a=0.3)$

藤堂正樹 : 固定化砂州での掘削路開削による洪水撹乱の誘 発と樹林化抑制対策に関する研究（その2），河川技術論 文集，第17巻, pp.233-238， 2011.

4) Klingeman, P.C. : 自然再生の河川工学, 山海堂, 2003.

5) Parker, G, Wilcock, P.R., Paola, C., Dietrich, W. and Pitlick, J.: Physical basis for quasi-universal relations describing bankfull hydraulic geometry of single-thread gravel bed rivers, Journal of Geophysical Research, Vol.112, F04005, 2007.

6) 池田駿介, Gary Parker, 千代田将明，木村善孝 : 直線磒床 河川の動的安定横断形状とそのスケール，土木学会論文集， 第375巻/II-6, pp.117-126, 1986.

7) 浅野文典, 福岡捷二 : 沖積地河川における安定な川幅・水 深一治水と環境の調和を目指した河道断面形の決め方，水 工学論文集, 第54巻, pp.1021-1026, 2010.

8）例えば, 清水康行 : 河道平面形状の形成における河床・河 岸の変動特性の相互関係について, 水工学論文集, 第47巻, pp.643-648, 2003.

9) 関根正人 : 斜面崩落モデルを用いた網状流路の形成過程シ ミュレーション, 水工学論文集, 第47巻, pp.637-642, 2003.

10）長田健吾, 小林幹男, 福岡捷二 : 連続水制を有する急流石 䃯河道札内川の洪水時の流れ・土砂動態に関する研究, 河 川技術論文集，第17巻，pp.149-154，2011.

11）例えば，音田慎一郎，白井秀和，細田尚，有光剛，大江一 也 : 急勾配湾曲水路の河床・河道変動に対する平衡 ・ 非平 衡流砂モデルの適用性について, 水工学論文集, 第54巻, pp.691-696, 2010.

12）例えば, 岩崎理樹, 清水康行, 木村一郎, 清治真人 : 蛇行 水路の河床変動及ひ分級現象に及ほす二次流の影響, 水工 学論文集, 第54巻, pp.739-744, 2010.

13) (社)砂防学会編 : 山地河川における河床変動の数值計算法, 山海堂, 2000.

14) Kulegan, G. H.: Laws of turbulent flow in open channels,

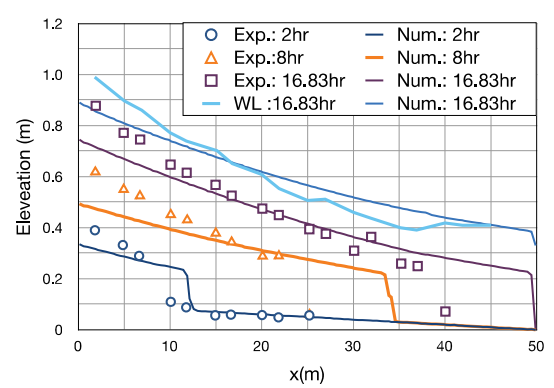

(a) 河床高 (WC-model)

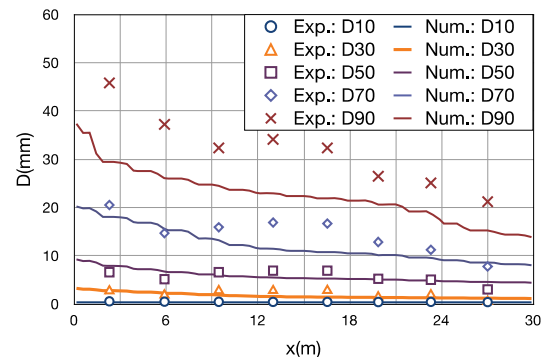

(b) 粒径 (WC-model)

図-7 河床と粒径の縦断変化 $(a=0.5)$ National Bureau of Standards Research papaer, RP 1151, Washington, D.C., 1938.

15) 平野宗夫 : Armoringを伴う河床低下について, 土木学会論 文報告集，第195号，pp.55-65，1971.

16）芦田和男，道上正規 : 移動床流れの抵抗と掃流砂量に関寸る 基礎的研究，土木学会論文報告集，第206号，pp.59-69， 1972.

17) Wilcock, P. R. and Crowe, J. C.: Surface-based transport model for mixed-sized sediment, Journal of Hydraulic Engineering, ASCE, Vol129. No.2, pp.120-128, 2003.

18) Hoey, T. B. and Ferguson, R. I.: Numerical simulation of downstream fining by selective transport in gravel bed rivers: Model development and illustration, Water Resources and Research, Vol.30, pp.2251-2260, 1994.

19) Toro-Escobar, C. M., Parker, G., and Paola, C.: Transfer function for the deposition of poorly sorted gravel in response to streambed aggradation, Journal of Hydraulic Research, Vol.34, No.1, pp.3554, 1996.

20) Toro, E. F.: Shock-capturing method for free-surface shallow flows, Wiley, New York, 2001.

21) 矢部孝, 内海孝行, 尾形陽一: CIP法〜原子から宇宙まで を説くマルチスケール解法〜，森北出版株式会社，2003.

22）秋山壽一郎・重枝未玲・小園裕司 : 流域特性を考慮した都 市域氾濫解析モデルと都市域での浸水プロセスの予知，水 工学論文集, 第54巻, pp.919-924, 2010.

23）芦田和男, 道上正規 : 混合砂碟の河床変動 armouring現象 について，第15回水理講演会公演集，pp.31-36, 1971.

24) Seal, R., Paola, C., Parker, G., Southard, J. B. and Wilcock, P.R.: Experiments on downstream fining of gravel: Part 1 narrow channel runs, Journal of Hydraulic Engineering, ASCE, Vol.126, No.3, pp.198-208, 1997.

(2011. 9. 30受付) 